\title{
The Emerging Function of PKCtheta in Cancer
}

\author{
Amandine Nicolle ${ }^{+}\left(\mathbb{D}\right.$, Ye Zhang $^{\dagger}$ and Karine Belguise ${ }^{*}(\mathbb{D}$ \\ MCD, Centre de Biologie Intégrative (CBI), Université de Toulouse, CNRS, UPS, 31062 Toulouse, France; \\ amandine.nicolle@univ-tlse3.fr (A.N.); ye.zhang@univ-tlse3.fr (Y.Z.) \\ * Correspondence: karine.belguise@univ-tlse3.fr \\ + Equivalent contribution.
}

\section{check for}

updates

Citation: Nicolle, A.; Zhang, Y.; Belguise, K. The Emerging Function of PKCtheta in Cancer. Biomolecules 2021, 11, 221. https://doi.org/ 10.3390/biom11020221

Academic Editors: Jose Bayascas and Peter Coopman

Received: 30 November 2020

Accepted: 2 February 2021

Published: 5 February 2021

Publisher's Note: MDPI stays neutral with regard to jurisdictional claims in published maps and institutional affiliations.

Copyright: (c) 2021 by the authors. Licensee MDPI, Basel, Switzerland. This article is an open access article distributed under the terms and conditions of the Creative Commons Attribution (CC BY) license (https:/ / creativecommons.org/licenses/by/ $4.0 /)$.

\begin{abstract}
Protein Kinase C theta (PKC $\theta$ ) is a serine/threonine kinase that belongs to the novel PKC subfamily. In normal tissue, its expression is restricted to skeletal muscle cells, platelets and T lymphocytes in which PKC $\theta$ controls several essential cellular processes such as survival, proliferation and differentiation. Particularly, PKC $\theta$ has been extensively studied for its role in the immune system where its translocation to the immunological synapse plays a critical role in $\mathrm{T}$ cell activation. Beyond its physiological role in immune responses, increasing evidence implicates PKC $\theta$ in the pathology of various diseases, especially autoimmune disorders and cancers. In this review, we discuss the implication of PKC $\theta$ in various types of cancers and the PKC $\theta$-mediated signaling events controlling cancer initiation and progression. In these types of cancers, the high PKC $\theta$ expression leads to aberrant cell proliferation, migration and invasion resulting in malignant phenotype. The recent development and application of PKC $\theta$ inhibitors in the context of autoimmune diseases could benefit the emergence of treatment for cancers in which PKC $\theta$ has been implicated.
\end{abstract}

Keywords: PKCtheta; cancer; tumoral function; mechanisms of action

\section{Introduction}

The Protein Kinase C (PKC) family is a family of serine/threonine kinases that are involved in various cellular processes for different cell types. The PKC family is classified into three subfamilies: classical $(\alpha, \beta I, \beta I I, \gamma)$, novel $(\delta, \varepsilon, \eta, \theta)$ and atypical $(\zeta, \iota / \lambda) \operatorname{PKC}$ isoforms. This classification is based on their structure and ability to respond to calcium and/or diacylglycerol (DAG) [1]. Among this family, the novel PKC $\theta$ isoform is different from other PKC isoforms since its physiological expression is limited to a few types of cells, such as T cells, platelets and skeletal muscle cells. This specific expression confers to this isoform a central role in the immune system where PKC $\theta$ controls T cell activation, survival and differentiation [2]. In skeletal muscle cells, PKC $\theta$ regulates muscle cell development, homeostasis and remodeling [3]. Beyond its physiological functions, PKC $\theta$ is also involved in the pathology of various diseases. In the context of the immune system and skeletal muscle tissue, the dysregulation of PKC $\theta$ activity leads to both autoimmune and inflammatory diseases and to insulin resistance and Type 2 diabetes, respectively [3,4]. In the last decade, growing evidence implicated the PKC $\theta$ signaling in the biology of cancer where it controls cancer cell proliferation, migration and invasion at the cytoplasmic or nuclear levels. Here, we discuss this emerging function of PKC $\theta$ in cancer by analyzing its diverse modes of action and their consequence on critical biological processes involved in tumorigenesis and cancer progression.

\section{PKC $\theta$ Structure and Physiological Function}

In this section, we provide a brief overview of the PKC $\theta$ structure and the PKC $\theta$ physiological function mainly in the immune system. For extensive details, the readers can refer to several excellent reviews written by the experts in the field of $\mathrm{T}$ cell biology (reviewed in [2,4-7]). 


\subsection{PKC $\theta$ Structure}

The novel PKC $\theta$ isoform is a protein kinase encoded by the PRKCQ gene and composed of 706 amino acids with a molecular weight of approximately $82 \mathrm{kDa}$ [8]. PKC $\theta$ is a DAG-dependent but $\mathrm{Ca}^{2+}$-independent, protein kinase whose structure consists of several functional domains that are conserved among the novel PKC subfamily (Figure 1) [1]. The $\mathrm{N}$-terminal regulatory domain contains the $\mathrm{C} 2$-like domain, the pseudosubstrate region and the DAG-binding domain $(\mathrm{C} 1 \mathrm{~A} / \mathrm{B})$ while the C-terminal catalytic domain contains the ATP-binding domain (C3) and the substrate-binding domain (C4). The regulatory and catalytic domains are separated by a hinge region, called the V3 motif, which is unique and highly specific to each PKC isoforms.

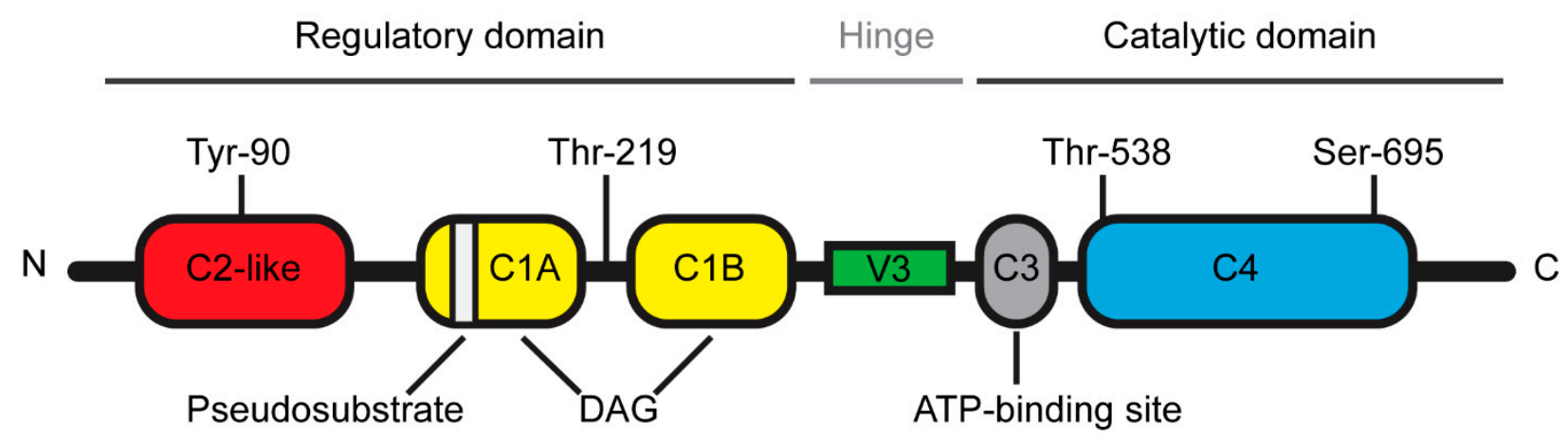

Figure 1. Schematic representation of Protein Kinase $C$ theta $(\mathrm{PKC} \theta)$ structure.

\subsection{PKC $\theta$ Function in the Immune System}

Due to the high expression levels of PKC $\theta$ in T lymphocytes, extensive research has studied the biological function of this novel PKC isoform in the immune system. The generation and analysis of PKC $\theta$-deficient mice have unraveled the selective role of PKC $\theta$ in the $\mathrm{T}$ cell immune response $[9,10]$. While PKC $\theta$ is critical for the T helper (Th)2- and Th17-mediated responses, the Th1- and cytotoxic $\mathrm{T}$ cell-driven responses remain relatively intact in the absence of PKC $[4,7]$. However, a few studies reported that some specific Th1 responses were altered in $\mathrm{PKC} \theta$ deficient mice $[11,12]$. T lymphocyte activation is a central step of the $\mathrm{T}$ cell immune response during which $\mathrm{T}$ cell interacts with an antigen-presenting cell (APC) [4]. This cell-cell junction forms a well-organized and dynamic structure called the immunological synapse [13]. Following this T cell-APC interaction, cytoplasmic PKC $\theta$ is translocated to the membrane at the immunological synapse [6] and this specific and critical relocalization is highly dependent on the unique V3 motif of PKC $\theta$ [14]. In addition, other events are also required for the proper localization and activation of PKC $\theta$ at the immunological synapse. Concerning the PKC $\theta$ localization, several studies indicated that the lck-mediated phosphorylation of PKC $\theta$ at tyr- 90 participated in the $\mathrm{PKC} \theta$ recruitment to the immunological synapse $[14,15]$ and a report from Thuille et al. suggested that the PKC $\theta$ autophosphorylation at thr-219 was required for the cell membrane localization of PKC $[16]$. Moreover, the data from Cartwright et al. suggested that PKC $\theta$ required its active kinase domain in order to be maintained at the immunological synapse [17]. More recently, Wang et al. reported that the sumoylation of PKC $\theta$ upon $\mathrm{T}$ cell activation was involved in the specific localization of PKC $\theta$ and in the organization of the immunological synapse [18]. Concerning the PKC $\theta$ activation, the phosphorylation at Thr-538 in the activation loop regulates the PKC $\theta$ activity by maintaining PKC $\theta$ in an active conformation and thus this phosphorylation has been used as a marker reflecting the PKC $\theta$ activation [19]. GCK-like kinase (GLK, MAP4K3) has been identified as one kinase capable of directly phosphorylating this Thr-538 residue during the T cell activation [20]. Moreover, the autophosphorylation at Ser-695 induced during T cell activation is also required for the PKC $\theta$ kinase activity $[19,21]$. 
Once translocated to the immunological synapse, $\mathrm{PKC} \theta$ integrates various signaling cascades that conduct to the activation of important transcription factors, including Nuclear Factor $\mathrm{kB}(\mathrm{NF}-\mathrm{kB})$, Activating Protein 1 (AP-1) and, to a lesser extent, Nuclear Factor of Activated T-cells (NFAT) [5]. This transcriptional machinery then induces the production of interleukin-2, a cytokine essential for the T cell proliferation [5]. Moreover, the PKC $\theta$ function is not only limited to the activation of signaling pathways that leads to the transcriptional regulation of gene expression. For example, PKC $\theta$ has been involved in the actin cytoskeletal reorganization that occurs during the formation of the immunological synapse and the related polarization of activated T cells $[18,22,23]$. PKC $\theta$ can also enter the nucleus of activated $\mathrm{T}$ cells to directly bind to the chromatin in order to regulate the expression of immune response genes and microRNAs involved in the cytokine regulation [24].

\subsection{Implication of PKC $\theta$ in Immunological Disorders}

As a selective regulator of the Th2 and Th17 immune responses, the perturbation of PKC $\theta$ expression and activity leads to the development of Th2-driven inflammatory diseases and Th17-mediated autoimmune diseases. Indeed, $\mathrm{PKC} \theta$ is highly expressed and activated in these immunological disorders [4]. Studies from the PKC $\theta$-deficient mice showed that the PKC $\theta$ suppression decreased the T cell inflammatory response in autoimmunity, allergy and allograft rejection [4]. Therefore, the therapeutic use of specific PKC $\theta$ inhibitors could provide an interesting approach for these $\mathrm{PKC} \theta$-dependent pathologies [25]. Clinical studies using sotrastaurin (AEB071) as the PKC $\theta$ inhibitor showed some encouraging results in the context of immunosuppressive therapy for autoimmune diseases such as psoriasis and organ transplantation $[4,26]$. However, sotrastaurin is not specific to PKC $\theta$ and it also shows strong and specific inhibitory activity against PKC $\alpha$ and PKC $\beta$ and to a lesser extend against $\mathrm{PKC} \delta, \mathrm{PKC} \varepsilon$ and $\mathrm{PKC}$. It thus suggests that sotrastaurin would inhibit not only the PKC $\theta$-mediated functions but also the functions from other PKCs [27]. Therefore, current research works aim to develop more selective PKC $\theta$ inhibitors $[28,29]$. These inhibitors are currently tested in mouse models and further studies are needed to validate them in the clinical trials.

\section{PKC $\theta$ Function in Cancer}

\subsection{Leukemia}

PKC $\theta$ has been proved to contribute a lot to the proliferation, activation and survival of cytotoxic lymphocytes and leukemic T cells. Using wild-type (WT) and PKC $\theta$-deficient mice with Moloney-murine leukemia virus, Garaude et al. studied the role of PKC $\theta$ in the $\mathrm{T}$ cell leukemia progression. They found that the incidence of leukemia was higher in the PKC $\theta$-deficient mice compared with that in the WT mice with the same type of leukemic cell and similar size of spleen and thymus, thus indicating that PKC $\theta$ plays an essential role in the immune response to leukemia in mice [30]. Besides, Notch signaling has been found to play an important role in the T-cell differentiation and leukemogenesis by interacting with the pre-T Cell Receptor pathway, which converges on the regulation of distinct NF- $\mathrm{kB}$ pathways [31]. Felli et al. found that PKC $\theta$ was a downstream target of Notch3 signaling and it could promote the development of the Notch3-induced T-cell leukemogenesis [32].

The graft-versus-leukemia (GVL) effect after allogeneic bone marrow transplantation (BMT) represents a powerful immunotherapy to cure hematopoietic malignancies, such as leukemia since the graft contains donor $T$ cells that can eliminate residual malignant cells [33]. However, the donor $\mathrm{T}$ cells also recognize the histocompatibility antigens of the healthy cells in the recipient and mount an immune attack against the recipient cells, thereby damaging the recipient organs. This potentially severe consequence of BMT that attacks the recipient body is called the graft-versus-host disease (GVHD). Besides, the commonly used agents that could limit GVDH by preventing the T cells activation are broadly immunosuppressive and can lead to the life-threatening infections. Thus, finding a therapeutic target to inhibit GVHD while maintaining the GVL effect as well as the immune response to the antigen at the same time is very important $[34,35]$. Using mouse 
models, Valenzuela et al. found that T cells lacking PKC $\theta$ were unable to undergo a strong expansion and cause damage to the recipient organs, while these T cells still maintain both GVL and virus infection responses after BMT [35]. These findings suggested that PKC $\theta$ could be a potential therapeutic target that is required for deleterious but not beneficial functions of donor T cells after BMT. Using genetic and pharmacologic approaches, Haarberg et al. confirmed that targeting $\mathrm{PKC} \theta$, together with $\mathrm{PKC} \alpha$, by using pharmacological inhibitors would be a good therapeutic strategy to inhibit GVHD while preserving functional GVL immune responses after BMT [36]. Concerning B-cell and T-cell acute lymphoblastic leukemia (ALL), different therapeutic approaches have been developed to cure these two subtypes of ALL. It is therefore important to identify markers that could rapidly distinguish these two types of ALL in order to apply the appropriate treatment. For this purpose, Ma et al. showed that PKC $\theta$ and CD3D (T-cell surface glycoprotein CD3 delta chain) together could help to discriminate the B-cell and T-cell ALL, while a single gene could not distinguish the two ALL subtypes effectively [37].

\subsection{Gastrointestinal Stromal Tumor}

Gastrointestinal stromal tumors (GIST) are the most common type of mesenchymal tumors of the gastrointestinal tract. GISTs harbor the gain-of-function mutations in the KIT oncogene, which leads to the overexpression of activated mutant KIT receptor tyrosine kinase. The overexpression of KIT plays an essential role in the development of GIST. The expression of KIT is regarded as the gold standard for the diagnosis of GIST based on histological and immunohistochemical method [38]. However, a small set of GIST (about $5 \%$ ) is KIT-negative, which causes diagnosis difficulties. Besides, imatinib, an inhibitor of KIT/PDGFRA kinase, is a standard therapy used to cure metastatic GIST; however, the low expression of c-kit oncoprotein in some GISTs could lead to the development of a therapeutic resistance [39]. Thus, finding a new marker to develop a highly specific and sensitive diagnostic tool and effective therapeutic strategy is an urgent need. Blay et al. analyzed the transcriptional profiling data of sarcomas and found that PKC $\theta$ was highly and specifically expressed in GIST but not in other mesenchymal or epithelial tumors, including non-GIST KIT-positive tumors [40]. Using immunohistochemistry to detect the expression of PKC $\theta$ and KIT in 48 samples of GIST, Motegi et al. found that PKC $\theta$ expression was positive in $85 \%$ of GISTs and was positive in all KIT-negative GISTs (6 samples), thus revealing that PKC $\theta$ could be a useful marker for GIST with negative-KIT [41]. The PKC $\theta$ antibody (clone $\mathrm{mAb} 27, \mathrm{BD}$ Bioscience) used in this study is specific to $\mathrm{PKC} \theta$, since it recognizes the C2-like domain of human PKC $\theta$ and does not cross-reacts with others PKC isozymes. This antibody has been used in the following studies detecting PKC $\theta$ in GIST and in breast tumors (see Section 3.3). In order to evaluate the utility of PKC $\theta$ as a diagnostic marker, Kim et al. characterized the expression levels of PKC $\theta$, KIT, CD34, $\alpha$-smooth muscle actin and S-100 protein by immunohistochemistry in a larger number of GISTs (220 samples) and found that almost all the cases were PKC $\theta$-positive or KIT-positive, which indicates that PKC $\theta$ could be an important diagnostic marker of GIST [42]. Zhu et al. studied the signaling pathways that are dependent on the KIT activation in GIST and found that PKC $\theta$ interacted with KIT in co-immunoprecipitation experiment [43]. Their data also indicated that the tyrosine phosphorylation of PKC $\theta$ was KIT-dependent in GIST [43]. By studying the effects of shRNA-mediated PKC $\theta$ knockdown in GIST cell lines, the same group found that PKC $\theta$ regulated the KIT expression in both imatinib-sensitive and imatinib-resistant GIST cell lines. PKC $\theta$ knockdown also led to a prominent decrease in the AKT activation and to a reduction of GIST cell proliferation. Consistent with the reduced cell growth, PKC $\theta$ knockdown resulted in an upregulation of cyclin-dependent kinase inhibitors p21 and p27 expression and a downregulation of cyclin A expression [44]. In a later study, Ou et al. found that PKC $\theta$, JUN and the Hippo pathway coordinately regulated the cyclin D1 expression in GIST [45]. Lately, a work from Kim et al. have explored the relationship between PKC $\theta$ and KIT expression by analyzing the expression of the mutant KIT protein that is the one 
overexpressed in GIST. They found that PKC $\theta$ mediated the stabilization of mutant KIT protein by increasing its retention in the Golgi [46].

\subsection{Breast Cancers}

We and other groups found that PKC $\theta$ was highly expressed in estrogen receptor negative (ER-) human breast tumors at transcript [47,48] and protein levels [49], whereas it was not expressed in normal breast epithelia and weakly expressed in ER+ breast tumors. The ER - breast cancers usually belong to the triple negative breast cancers (TNBC) since the epithelial breast cancer cells, which do not express the estrogen receptor, often do not express the progesterone receptor and the Her 2 protein. The TNBC are more invasive tumors compared to the ER+ ones. In addition to tumor samples, we also found that PKC $\theta$ was also highly expressed in the TNBC cell lines compared to the ER+ ones and it is present under its active form as reflected by the expression of phosphoThr-538 PKC $\theta[48,50]$. Our group investigated the cytoplasmic role of PKC $\theta$ in cancer cells and we showed that PKC $\theta$ was implicated in the mammary tumorigenesis induced by c-Rel, a member of NF- $\mathrm{kB}$ family. We discovered a novel NF- $\mathrm{KB}$ activation pathway by PKC $\theta$. More precisely, we found that a high level of PKC $\theta$ inhibited ER $\alpha$ expression through the activation of the Akt/FOXO3A pathway. Then, this inhibition resulted in the increase of c-Rel activity and to the transcription of c-Rel target genes (implicated in growth and survival such as c-Myc), thereby leading to tumorigenesis [48]. Consistently, we also found that PKC $\theta$ increased the expression of RelB (unpublished data), another NF- $\mathrm{KB}$ family member that inhibits ER $\alpha$ expression [51] and that promotes mesenchymal phenotype of breast cancer cells [52]. Later, we uncovered another role of cytoplasmic PKC $\theta$ and reported that PKC $\theta$ induced the migration and invasion of breast cancer cells. Mechanistically, PKC $\theta$ activation increased the phosphorylations of FRA-1, a member of AP-1 family. These PKC $\theta$-mediated phosphorylations increased the protein stability and transcriptional activity of FRA-1, thereby inducing the expression of FRA-1 target genes (implicated in cell migration and invasion such as MMP-1) [50,53]. We showed that PKC $\theta$ did not directly phosphorylate the FRA-1 protein but acted through the ERK and SPAK pathways to stabilize the FRA-1 protein [50]. In addition to its localization in the cytoplasm, PKC $\theta$ in its active form (phosphoThr-538 PKC $\theta$ ) was also found to distribute in the nucleus of TNBC cells [54]. However, while the data from Zafar et al. indicated that PKC $\theta$ exclusively localized into the nucleus of TNBC cells [54], in our hand, PKC $\theta$ localization in TNBC cells appeared to be mainly cytoplasmic with a small fraction present in the nucleus (unpublished data). This discrepancy may be due to the subcellular fractionation methods (not described in Zafar et al. publication) and/or the PKC $\theta$ antibodies used by both groups (sc-212, Santa Cruz antibody used by Zafar et al.; and E1I7Y, Cell Signaling Technology and clone mAb 27, BD Bioscience antibodies used by our group). Supporting the idea of an active role for PKC $\theta$ in the nucleus, a previous report showed that phosphoinositide signaling that generates DAG, a PKC $\theta$ co-activator, appeared to be intact in the nucleus [55]. In breast cancer cells, Zafar et al. found that chromatin-boundPKC $\theta$ was part of an active transcription complex that controlled the expression of genes involved in the epithelial to mesenchymal transition (EMT) and cancer stem cell [54,56]. Through this transcriptional control, PKC $\theta$ promoted EMT, a key process implicated in the initiation of metastasis in cancer. Sutcliffe et al. described that Chromatin-boundPKC $\theta$ negatively regulated microRNAs transcription, such as miR-200c and miR-9, in T cells [24]. These microRNAs are key factors in tumor metastasis [57] suggesting that they could also play a relevant role in EMT process in invasive breast cancer cells with high level of PKC $\theta$. Later, Boulding et al. found that Chromatin-bound-PKC $\theta$ phosphorylated Lysine-specific demethylase 1 (LSD1) to regulate its demethylase activity and promote LSD1 effect on EMT [58]. Altogether, these studies showed that PKC $\theta$ was implicated in various steps of breast cancer progression such as proliferation, migration and invasion. Thus, targeting PKC $\theta$ could be a good combinatorial therapeutic approach since TNBCs are unresponsive to hormonotherapy and often become resistant to chemotherapy. In fact, PKC $\theta$ expression was reported to be increased in MCF7/ADR cells, a MCF7 breast cancer 
cell line that acquired resistance against the chemotherapeutic agent, adriamycin [59]. More recently, PKC $\theta$ has been shown to lower apoptosis induced by chemotherapeutic agents (doxorubicin/adriamycin and paclitaxel) [60]. Byerly et al. found that inhibiting PKC $\theta$ kinase activity in TNBC cells enhanced the chemotherapy sensitivity by modulating the expression of Bim, a pro-apoptotic BCL2-family protein [60] and PKC $\theta$ knockdown reduced tumor growth of TNBC cells [61]. To conclude, cytoplasmic and nuclear PKC $\theta$ are involved in breast cancer progression and chemoresistance.

\subsection{Other Cancers}

In a mouse model of lung cancer, the adaptor protein, TBK-binding protein 1 (TBKBP1), has been shown to mediate PKC $\theta$ direct phosphorylation of TANK-binding kinase 1 (TBK1) in response to epidermal growth factor (EGF) stimulation, leading to the activation of the oncogenic activity of TBK1. TBK1 was also responsible for the EGF induction of PD1 ligand 1 (PD-L1), a protein implicated in immunosuppression. Altogether, these data described a PKC $\theta-T B K B P 1-T B K 1$ signaling pathway that would control tumor growth and immunosuppression [62]. In renal cancer cells, the natural compounds, englerin $A$ and tonantzitlolone, were reported to activate PKC $\theta$ and act as an anti-tumor agent in a PKC $\theta$-dependent manner. By activating $\mathrm{PKC} \theta$, these compounds induced an insulin resistant phenotype in tumor cells through the activation of the heat shock factor 1 (HSF1) [63,64]. PKC $\theta$ has also been proposed to phosphorylate and inhibit the activity of the $\mathrm{G} \alpha$-interacting, vesicle-associated protein (GIV) in Hela cells, thereby inhibiting Akt activation, actin stress fiber formation and cell migration [65]. Chu et al. found an aberrant expression of PKC $\theta$ in oral squamous cell carcinoma and their data suggested that high nuclear PKC $\theta$ expression could correlate with disease recurrence and poor survival [66]. In ovarian cancer, phosphorylated PKC $\theta$ (Ser-695) has been detected at the protein level, however its function is unknown in this type of cancer [67]. Cytoplasmic PKC $\theta$ was also expressed in Ewing sarcoma/primitive neuroectodermal tumor (ES/PNETs) and in malignant peripheral nerve sheath tumors (MPNSTS). Specific "dot-like" pattern of PKC $\theta$ staining could be useful for the diagnosis in ES/PNETs, although the role of PKC $\theta$ remains unknown in both ES/PNETs and MPNSTS [68]. Exploring PKC $\theta$ expression in other cancers might be interesting and deciphering the function of this protein in all these cancers could be important to understand its pathological function.

\section{Perspectives}

As summarized in Table 1, the function and mode of action of PKC $\theta$ are different depending on the type of cancer. However, in most of these cancers, the presence of a strong PKC $\theta$ level leads to the abnormal proliferation, migration and invasion of tumor cells, thereby promoting tumor aggressiveness. The PKC $\theta$-mediated control of the tumor aggressiveness is somehow different from the PKC $\theta$-mediated physiological control of the immune response (Figure 2). However, these two controls share some similarities. Indeed, PKC $\theta$ can activate AP-1 and NF- $\kappa B$ transcription factors in both tumor cells and T cells but with the implication of different AP-1 and NF- $\mathrm{KB}$ subunits. Moreover, PKC $\theta$-mediated control can occur either in the cytoplasm or in the nucleus of both tumor cells and T cells. 
Table 1. Summary of PKC $\theta$ function and mode of action in various cancer types.

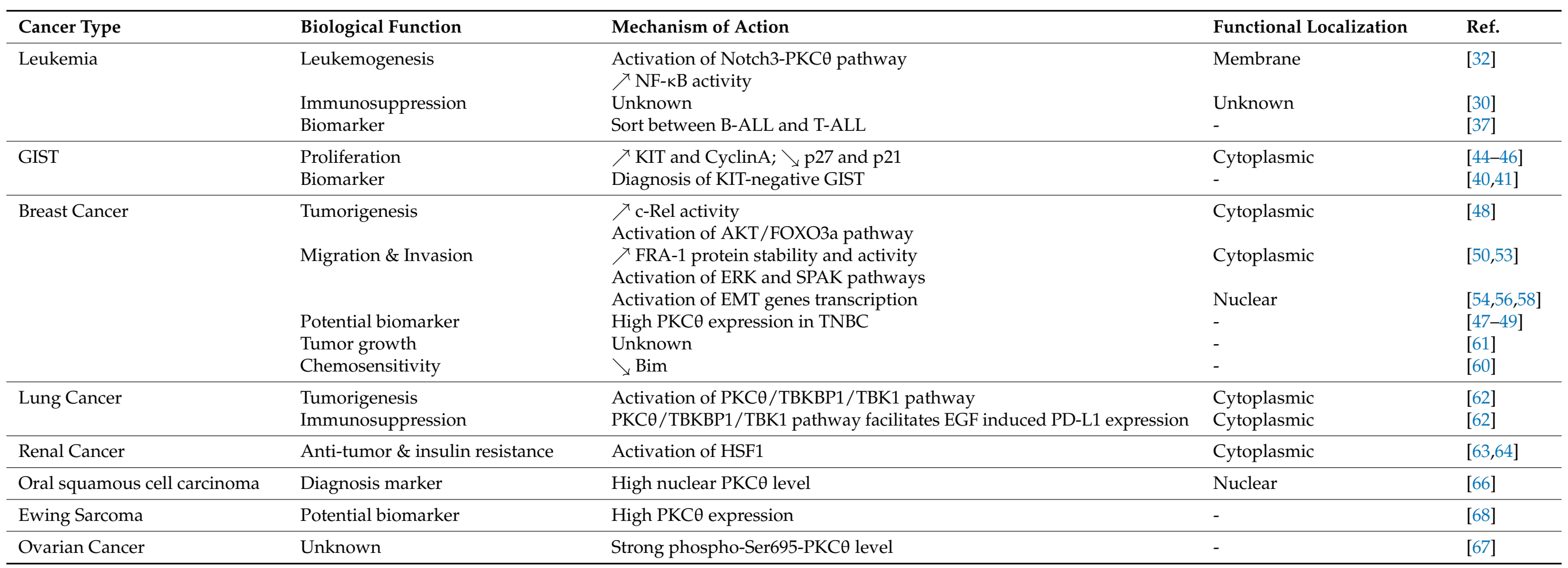

B-ALL: B-cell acute lymphoblastic leukemia. T-ALL: T-cell acute lymphoblastic leukemia. TNBC: Triple Negative Breast Cancer. 

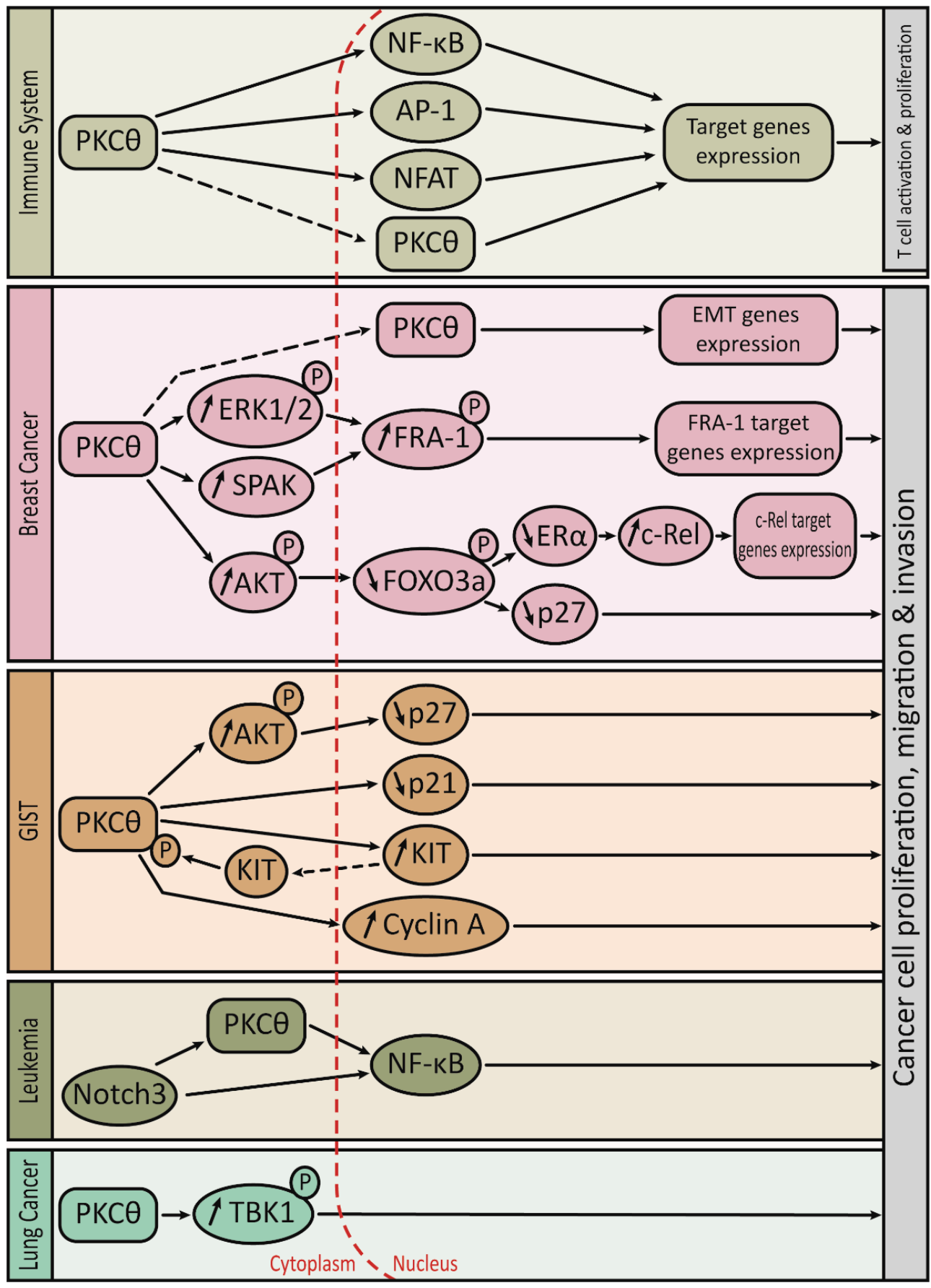

Figure 2. Cartoon summarizing the PKC $\theta$-mediated signaling pathways controlling the immune response and the tumor aggressiveness.

The challenge for cancer researchers is now to further clarify whether PKC $\theta$ tumoral function is dependent on its kinase activity and to clearly define PKC $\theta$ as a new therapeutic target for human cancers such as GIST and aggressive breast cancers. The use of specific PKC $\theta$ inhibitors may provide a new cancer therapy strategy for these types of cancer that are difficult to treat. Considering that the PKC $\theta$ knock-out mice are generally healthy and fertile, we would expect that the use of specific PKC $\theta$ inhibitors as cancer therapy would inhibit the proliferative and invasive ability of this kinase while producing minimal toxic side effects $[9,10]$. Moreover, the role of PKC $\theta$ in the immune system could provide additional benefit to such cancer therapy. Indeed, the immune system is involved in the 
control of tumor progression at two opposite directions: on the one hand, it possesses an inhibitory effect on the development of the tumor via the activation of Th1 responses that are PKC $\theta$-independent and on the other hand, it could promote the tumor invasion by activating the Th2 responses that are PKC $\theta$-dependent [69]. Thus, the use of specific inhibitors could not only block the PKC $\theta$ intrinsic function in tumor cells but could also suppress the Th2-driven pro-invasive function of the microenvironment.

Author Contributions: Conceptualization K.B.; Writing Original Draft Preparation A.N., Y.Z., K.B.; Figure Preparation A.N., K.B.; Writing Review \& Editing A.N., Y.Z., K.B. Funding Acquisition K.B.; All authors have read and agreed to the published version of the manuscript.

Funding: This work was supported by La Ligue Contre le Cancer (Comité de Haute-Garonne), La Ligue Contre le Cancer and Fondation ARC (PhD fellowship to A.N.), China Scholarship Council (PhD fellowship to Y.Z.).

Institutional Review Board Statement: Not applicable.

Informed Consent Statement: Not applicable.

Data Availability Statement: Not applicable.

Acknowledgments: We thank Xiaobo Wang for scientific input on this manuscript.

Conflicts of Interest: The authors declare no conflict of interest.

\section{References}

1. Steinberg, S.F. Structural basis of protein kinase C isoform function. Physiol. Rev. 2008, 88, 1341-1378. [CrossRef]

2. Hayashi, K.; Altman, A. Protein kinase C theta (PKCtheta): A key player in T cell life and death. Pharmacol. Res. 2007, 55, 537-544. [CrossRef]

3. Marrocco, V.; Fiore, P.; Madaro, L.; Crupi, A.; Lozanoska-Ochser, B.; Bouché, M. Targeting PKCtheta in skeletal muscle and muscle diseases: Good or bad? Biochem. Soc. Trans. 2014, 42, 1550-1555. [CrossRef]

4. Zhang, Y.E.; Kong, K.F.; Altman, A. The yin and yang of protein kinase C-theta (PKCtheta): A novel drug target for selective immunosuppression. Adv. Pharmacol. 2013, 66, 267-312.

5. Isakov, N.; Altman, A. Protein kinase C(theta) in T cell activation. Annu. Rev. Immunol. 2002, 20, 761-794. [CrossRef] [PubMed]

6. Kong, F.K.; Altman, A. In and out of the bull's eye: Protein kinase Cs in the immunological synapse. Trends Immunol. 2013, 34, 234-342. [CrossRef]

7. Marsland, J.B.; Kopf, M. T-cell fate and function: PKC-theta and beyond. Trends Immunol. 2008, 29, 179-185. [CrossRef] [PubMed]

8. Baier, G.; Telford, D.; Giampa, L.; Coggeshall, K.M.; Bitterlich, G.B.; Isakov, N.; Altman, A. Molecular cloning and characterization of PKC theta, a novel member of the protein kinase C (PKC) gene family expressed predominantly in hematopoietic cells. J. Biol. Chem. 1993, 268, 4997-5004. [CrossRef]

9. Pfeifhofer, C.; Kofler, K.; Gruber, T.; Tabrizi, N.G.; Lutz, C.; Maly, K.; Leitges, M.; Baier, G. Protein kinase C theta affects Ca2+ mobilization and NFAT cell activation in primary mouse T cells. J. Exp. Med. 2003, 197, 1525-1535. [CrossRef] [PubMed]

10. Sun, Z.; Arendt, C.W.; Ellmeier, W.; Schaeffer, E.M.; Sunshine, M.J.; Gandhi, L.; Annes, J.; Petrzilka, D.; Kupfer, A.; Schwartzberg, P.L.; et al. PKC-theta is required for TCR-induced NF-kappaB activation in mature but not immature T lymphocytes. Nature 2000, 404, 402-407. [CrossRef]

11. Nishanth, G.; Burkiewicz, M.S.; Händel, U.; Kliche, S.; Wang, X.; Naumann, M.; Deckert, M.; Schlüter, D. Protective Toxoplasma gondii-specific T-cell responses require T-cell-specific expression of protein kinase C-theta. Infect. Immun. 2010, 78, 3454-3464. [CrossRef] [PubMed]

12. Ohayon, A.; Golenser, J.; Sinay, R.; Tamir, A.; Altman, A.; Pollack, Y.; Isakov, N. Protein kinase C theta deficiency increases resistance of C57BL/6J mice to Plasmodium berghei infection-induced cerebral malaria. Infect. Immun. 2010, 78, $4195-4205$. [CrossRef] [PubMed]

13. Grakoui, A.; Bromley, S.K.; Sumen, C.; Davis, M.M.; Shaw, A.S.; Allen, P.M.; Dustin, M.L. The immunological synapse: A molecular machine controlling T cell activation. Science 1999, 285, 221-227. [CrossRef] [PubMed]

14. Kong, K.O.; Yokosuka, T.; Balancio, A.J.C.; Isakov, N.; Saito, T.; Altman, A. A motif in the V3 domain of the kinase PKC-theta determines its localization in the immunological synapse and functions in T cells via association with CD28. Nat. Immunol. 2011, 12, 1105-1112. [CrossRef]

15. Liu, Y.; Witte, S.; Liu, Y.C.; Doyle, M.; Elly, C.; Altman, A. Regulation of protein kinase Ctheta function during T cell activation by Lck-mediated tyrosine phosphorylation. J. Biol. Chem. 2000, 275, 3603-3609. [CrossRef]

16. Thuille, N.; Heit, I.; Fresser, F.; Krumböck, N.; Bauer, B.; Leuthaeusser, S.; Dammeier, S.; Graham, C.; Copeland, T.D.; Shaw, S.; et al. Critical role of novel Thr-219 autophosphorylation for the cellular function of PKCtheta in T lymphocytes. EMBO J. 2005, 24, 3869-3880. [CrossRef] [PubMed] 
17. Cartwright, G.N.; Kashyap, A.K.; Schaefer, B.C. An active kinase domain is required for retention of PKCtheta at the T cell immunological synapse. Mol. Biol. Cell 2011, 22, 3491-3497. [CrossRef]

18. Wang, X.D.; Gong, Y.; Chen, Z.L.; Gong, B.N.; Xie, J.J.; Zhong, C.Q.; Wang, Q.L.; Diao, L.H.; Xu, A.; Han, J.; et al. TCR-induced sumoylation of the kinase PKC-theta controls T cell synapse organization and T cell activation. Nat. Immunol. 2015, 16, 1195-1203. [CrossRef]

19. Liu, Y.; Graham, C.; Li, A.; Fisher, R.J.; Shaw, S. Phosphorylation of the protein kinase C-theta activation loop and hydrophobic motif regulates its kinase activity, but only activation loop phosphorylation is critical to in vivo nuclear-factor-kappaB induction. Biochem. J. 2002, 361, 255-265. [CrossRef]

20. Chuang, H.C.; Lan, J.L.; Chen, d.; Yang, C.Y.; Chen, Y.M.; Li, J.P.; Huang, C.Y.; Liu, P.E.; Wang, X.; Tan, T.H. The kinase GLK controls autoimmunity and NF-kappaB signaling by activating the kinase PKC-theta in T cells. Nat. Immunol. 2011, 12, 1113-1118. [CrossRef]

21. Czerwinski, R.; Aulabaugh, A.; Greco, R.M.; Olland, S.; Malakian, K.; Wolfrom, S.; Lin, L.; Kriz, R.; Stahl, M.; Huang, Y.; et al. Characterization of protein kinase $C$ theta activation loop autophosphorylation and the kinase domain catalytic mechanism. Biochemistry 2005, 44, 9563-9573. [CrossRef]

22. Britton, G.J.; Ambler, R.; Clark, D.J.; Hill, E.V.; Tunbridge, H.M.; McNally, K.E.; Burton, B.R.; Butterweck, P.; Peyton, C.S.; O’Neil, L.A.H.; et al. PKCtheta links proximal T cell and Notch signaling through localized regulation of the actin cytoskeleton. Elife 2017, 6, e20003. [CrossRef] [PubMed]

23. Quann, E.J.; Liu, X.; Bonnet, G.A.; Huse, M. A cascade of protein kinase C isozymes promotes cytoskeletal polarization in T cells. Nat. Immunol. 2011, 12, 647-654. [CrossRef]

24. Sutcliffe, E.L.; Bunting, K.L.; He, Y.Q.; Li, J.; Phetsouphanh, C.; Seddiki, N.; Zafar, A.; Hindmarsh, E.J.; Parish, C.R.; Kelleher, A.D.; et al. Chromatin-associated protein kinase C-theta regulates an inducible gene expression program and microRNAs in human $\mathrm{T}$ lymphocytes. Mol. Cell 2011, 41, 704-719. [CrossRef] [PubMed]

25. Kwon, M.Y.; Wang, R.; Ma, J.; Sun, Z. PKC-theta is a drug target for prevention of T cell-mediated autoimmunity and allograft rejection. Endocr. Metab. Immune Disord. Drug Targets 2010, 10, 367-372. [CrossRef]

26. Sleiman, R.H.; Hamze, A.B.; Reslan, L.; Kobeissy, H.; Dbaibo, G. The Novel PKCtheta from Benchtop to Clinic. J. Immunol. Res. 2015, 2015, 348798.

27. Evenou, J.P.; Wagner, J.; Zenke, G.; Brinkmann, V.; Wagner, K.; Kovarik, J.; Welzenbach, K.A.; Schmidt, G.W.; Guntermann, C.; Towbin, H.; et al. The potent protein kinase C-selective inhibitor AEB071 (sotrastaurin) represents a new class of immunosuppressive agents affecting early T-cell activation. J. Pharmacol. Exp. Ther. 2009, 330, 792-801. [CrossRef]

28. Kunikawa, S.; Tanaka, A.; Takasuna, Y.; Tasaki, M.; Chida, N. Discovery of 2,4-diamino-5-cyanopyrimidine derivatives as protein kinase $C$ theta inhibitors with mitigated time-dependent drug-drug interactions. Bioorg. Med. Chem. 2019, 27, 790-799. [CrossRef]

29. Wang, J.; Jin, W.; Zhou, X.; Li, J.; Xu, C.; Ma, Z.; Wang, J.; Qin, L.; Zhou, B.; Ding, W.; et al. Identification, Structure-Activity Relationships of Marine-Derived Indolocarbazoles, and a Dual PKCtheta/delta Inhibitor with Potent Antipancreatic Cancer Efficacy. J. Med. Chem. 2020, 63, 12978-12991. [CrossRef]

30. Garaude, J.; Kaminski, S.; Charni, S.; Aguilò, J.I.; Jacquet, C.; Plays, M.; Hernandez, J.; Rodriguez, F.; Hipskind, R.A.; Anel, A.; et al. Impaired anti-leukemic immune response in PKCtheta-deficient mice. Mol. Immunol. 2008, 45, 3463-3469. [CrossRef]

31. Vacca, A.; Felli, M.P.; Palermo, R.; di Mario, G.; Calce, A.; di Giovine, M.; Frati, L.; Gulino, A.; Screpanti, I. Notch3 and pre-TCR interaction unveils distinct NF-kappaB pathways in T-cell development and leukemia. EMBO J. 2006, 25, 1000-1008. [CrossRef] [PubMed]

32. Felli, M.P.; Vacca, A.; Calce, A.; Bellavia, D.; Campese, A.F.; Grillo, R.; di Giovine, M.; Checquolo, S.; Talora, C.; Palermo, R.; et al. PKC theta mediates pre-TCR signaling and contributes to Notch3-induced T-cell leukemia. Oncogene 2005, 24, 992-1000. [CrossRef]

33. Appelbaum, F.R. Haematopoietic cell transplantation as immunotherapy. Nature 2001, 411, 385-389. [CrossRef]

34. Isakov, N.; Altman, A. PKC-theta-mediated signal delivery from the TCR/CD28 surface receptors. Front. Immunol. 2012, 3, 273. [CrossRef]

35. Valenzuela, J.O.; Iclozan, C.; Hossain, M.S.; Prlic, M.; Hopewell, E.; Bronk, C.C.; Wang, J.; Celis, E.; Engelman, R.W.; Blazar, B.R.; et al. PKCtheta is required for alloreactivity and GVHD but not for immune responses toward leukemia and infection in mice. J. Clin. Investig. 2009, 119, 3774-37786. [CrossRef]

36. Haarberg, K.M.K.; Li, J.; Heinrichs, J.; Wang, D.; Liu, C.; Bronk, C.C.; Kaosaard, K.; Owyang, A.M.; Holland, S.; Masuda, E.; et al. Pharmacologic inhibition of PKCalpha and PKCtheta prevents GVHD while preserving GVL activity in mice. Blood 2013, 122, 2500-2511. [CrossRef]

37. Ma, D.; Zhong, S.; Liu, X.; Mai, H.; Mai, G.; Xu, C.; Zhou, F. CD3D and PRKCQ work together to discriminate between B-cell and T-cell acute lymphoblastic leukemia. Comput. Biol. Med. 2016, 77, 16-22. [CrossRef] [PubMed]

38. Fletcher, C.D.M.; Berman, J.J.; Corless, C.; Gorstein, F.; Lasota, J.; Longley, B.J.; Miettinen, M.; O'Leary, T.J.; Remotti, H.; Rubin, B.P.; et al. Diagnosis of gastrointestinal stromal tumors: A consensus approach. Hum. Pathol. 2002, 33, 459-465. [CrossRef] [PubMed]

39. Ding, H.; Yu, X.; Yu, Y.; Lao, X.; Hang, C.; Gao, K.; Jia, Y.; Yan, Z. Clinical significance of the molecular heterogeneity of gastrointestinal stromal tumors and related research: A systematic review. Oncol. Rep. 2020, 43, 751-764. [CrossRef] 
40. Blay, P.; Astudillo, A.; Buesa, J.M.; Campo, E.; Abad, M.; García, J.G.; Miquel, R.; Marco, V.; Sierra, M.; Losa, R.; et al. Protein kinase $\mathrm{C}$ theta is highly expressed in gastrointestinal stromal tumors but not in other mesenchymal neoplasias. Clin. Cancer Res. 2004, 10, 4089-4095. [CrossRef]

41. Motegi, A.; Sakurai, S.; Nakayama, H.; Sano, T.; Oyama, T.; Nakajima, T. PKC theta, a novel immunohistochemical marker for gastrointestinal stromal tumors (GIST), especially useful for identifying KIT-negative tumors. Pathol. Int. 2005, 55, 106-112. [CrossRef] [PubMed]

42. Kim, K.M.; Kang, D.W.; Moon, W.S.; Park, J.B.; Park, C.K.; Sohn, J.H.; Jeong, J.S.; Cho, M.; Jin, S.; Choi, J.S. PKCtheta expression in gastrointestinal stromal tumor. Mod. Pathol. 2006, 19, 1480-1486. [CrossRef] [PubMed]

43. Zhu, M.J.; Ou, W.B.; Fletcher, C.D.M.; Cohen, P.S.; Demetri, G.D.; Fletcher, J.A. KIT oncoprotein interactions in gastrointestinal stromal tumors: Therapeutic relevance. Oncogene 2007, 26, 6386-6395. [CrossRef]

44. Ou, W.B.; Zhu, M.J.; Demetri, G.D.; Fletcher, C.D.M.; Fletcher, J.A. Protein kinase C-theta regulates KIT expression and proliferation in gastrointestinal stromal tumors. Oncogene 2008, 27, 5624-5664. [CrossRef]

45. Ou, W.B.; Ni, N.; Zuo, R.; Zhuang, W.; Zhu, M.; Kyriazoglou, A.; Wu, D.; Eilers, G.; Demetri, G.D.; Qiu, H.; et al. Cyclin D1 is a mediator of gastrointestinal stromal tumor KIT-independence. Oncogene 2019, 38, 6615-6629. [CrossRef] [PubMed]

46. Kim, W.K.; Yun, S.; Park, C.K.; Bauer, S.; Kim, J.; Lee, M.G.; Kim, H. Sustained Mutant KIT Activation in the Golgi Complex Is Mediated by PKC-theta in Gastrointestinal Stromal Tumors. Clin. Cancer Res. 2017, 23, 845-856. [CrossRef] [PubMed]

47. Chin, K.; deVries, S.; Fridlyand, J.; Spellman, P.T.; Roydasgupta, R.; Kuo, W.B.; Lapuk, A.; Neve, R.M.; Qian, Z.; Ryder, T.; et al. Genomic and transcriptional aberrations linked to breast cancer pathophysiologies. Cancer Cell 2006, 10, 529-541. [CrossRef] [PubMed]

48. Belguise, K.; Sonenshein, G.E. PKCtheta promotes c-Rel-driven mammary tumorigenesis in mice and humans by repressing estrogen receptor alpha synthesis. J. Clin. Investig. 2007, 117, 4009-4021. [PubMed]

49. Soyombo, A.A.; Wu, Y.; Kolski, L.; Rios, J.J.; Rakheja, D.; Chen, A.; Kehler, J.; Hampel, H.; Coughran, A.; Ross, T.S. Analysis of induced pluripotent stem cells from a BRCA1 mutant family. Stem Cell Rep. 2013, 1, 336-349. [CrossRef] [PubMed]

50. Belguise, K.; Milord, S.; Galtier, F.; Torcy, G.M.; Piechaczyk, M.; Chalbos, D. The PKCtheta pathway participates in the aberrant accumulation of Fra-1 protein in invasive ER-negative breast cancer cells. Oncogene 2012, 31, 4889-4897. [CrossRef] [PubMed]

51. Wang, X.; Belguise, K.; O’Neill, C.F.; Morgan, N.S.; Romagnoli, M.; Eddy, S.F.; Mineva, N.D.; Yu, Z.; Min, C.; Randall, V.T.; et al. RelB NF-kappaB represses estrogen receptor alpha expression via induction of the zinc finger protein Blimp1. Mol. Cell Biol. 2009, 29, 3832-3844. [CrossRef]

52. Wang, X.; Belguise, K.; Kersual, N.; Kirsch, K.H.; Mineva, N.D.; Galtier, F.; Chalbos, D.; Sonenshein, G.E. Oestrogen signalling inhibits invasive phenotype by repressing RelB and its target BCL2. Nat. Cell Biol. 2007, 9, 470-478. [CrossRef] [PubMed]

53. Belguise, K.; Cherradi, S.; Sarr, A.; Boissière, F.; Boulle, N.; Lafontaine, J.S.; Cadamuro, V.C.; Wang, X.; Chalbos, D. PKCthetainduced phosphorylations control the ability of Fra-1 to stimulate gene expression and cancer cell migration. Cancer Lett. 2017, 385, 97-107. [CrossRef]

54. Zafar, A.; Wu, F.; Hardy, K.; Li, J.; Tu, W.J.; McCuaig, R.; Harris, J.; Khanna, K.K.; Attema, J.; Gregory, P.A.; et al. Chromatinized protein kinase $\mathrm{C}$-theta directly regulates inducible genes in epithelial to mesenchymal transition and breast cancer stem cells. Mol. Cell Biol. 2014, 34, 2961-2980. [CrossRef]

55. Visnjic, D.; Banfic, H. Nuclear phospholipid signaling: Phosphatidylinositol-specific phospholipase C and phosphoinositide 3-kinase. Pflügers Arch. Eur. J. Physiol. 2007, 455, 19-30. [CrossRef] [PubMed]

56. Zafar, A.; Hardy, K.; Wu, F.; Li, J.; Rao, S. The role of protein kinase-C theta in control of epithelial to mesenchymal transition and cancer stem cell formation. Genom. Data 2015, 3, 28-32. [CrossRef]

57. Gregory, P.A.; Bert, A.G.; Paterson, E.L.; Barry, S.C.; Tsykin, A.; Farshid, G.; Vadas, M.A.; Goodall, Y.K.; Goodall, G.J. The miR-200 family and miR-205 regulate epithelial to mesenchymal transition by targeting ZEB1 and SIP1. Nat. Cell Biol. 2008, 10, 593-601. [CrossRef]

58. Boulding, T.; McCuaig, R.D.; Tan, A.; Hardy, K.; Wu, F.; Dunn, J.; Kalimutho, M.; Sutton, C.R.; Forwood, J.K.; Bert, A.G.; et al. LSD1 activation promotes inducible EMT programs and modulates the tumour microenvironment in breast cancer. Sci. Rep. 2018, 8, 73. [CrossRef] [PubMed]

59. Gill, K.P.; Gescher, A.; Gant, W.T. Regulation of MDR1 promoter activity in human breast carcinoma cells by protein kinase C isozymes alpha and theta. Eur. J. Biochem. 2001, 268, 4151-4157. [CrossRef] [PubMed]

60. Byerly, H.J.; Port, E.R.; Irie, Y.H. PRKCQ inhibition enhances chemosensitivity of triple-negative breast cancer by regulating Bim. Breast Cancer Res. 2020, 22, 72. [CrossRef]

61. Byerly, J.; Nussloch, G.H.; Ito, K.; Katsyv, I.; Irie, H.Y. PRKCQ promotes oncogenic growth and anoikis resistance of a subset of triple-negative breast cancer cells. Breast Cancer Res. 2016, 18, 95. [CrossRef] [PubMed]

62. Zhu, L.; Li, Y.; Xie, X.; Zhou, X.; Gu, M.; Jie, Z.; Ko, C.J.; Gao, T.; Hernandez, B.E.; Cheng, X.; et al. TBKBP1 and TBK1 form a growth factor signalling axis mediating immunosuppression and tumourigenesis. Nat. Cell Biol. 2019, 21, 1604-1614. [CrossRef]

63. Sourbier, C.; Scroggins, B.T.; Mannes, P.Z.; Liao, P.J.; Siems, K.; Wolf, D.; Beutler, J.A.; Linehan, W.M.; Necker, L.S. Tonantzitlolone cytotoxicity toward renal cancer cells is PKCtheta- and HSF1-dependent. Oncotarget 2015, 6, 29963-29974. [CrossRef]

64. Sourbier, C.; Scroggins, B.T.; Ratnayake, R.; Prince, T.L.; Lee, S.; Lee, M.J.; Nagy, P.L.; Lee, Y.H.; Trepel, J.B.; Beutler, J.A.; et al. Englerin A stimulates PKCtheta to inhibit insulin signaling and to simultaneously activate HSF1: Pharmacologically induced synthetic lethality. Cancer Cell 2013, 23, 228-237. [CrossRef] 
65. Sánchez, I.L.; Marcos, M.G.; Mittal, Y.; Aznar, N.; Farquhar, M.G.; Ghosh, P. Protein kinase C-theta (PKCtheta) phosphorylates and inhibits the guanine exchange factor, GIV/Girdin. Proc. Natl. Acad. Sci. USA 2013, 110, 5510-5515. [CrossRef]

66. Chu, P.Y.; Hsu, N.C.H.; Tai, H.C.; Yeh, C.M.; Lin, S.H.; Hou, M.F.; Yeh, K.T. High nuclear protein kinase Ctheta expression may correlate with disease recurrence and poor survival in oral squamous cell carcinoma. Hum. Pathol. 2012, 43, 276-281. [CrossRef] [PubMed]

67. Hu, Y.; Sun, L.; Zhang, Y.; Lang, J.; Rao, J. Phosphoproteomics Reveals Key Regulatory Kinases and Modulated Pathways Associated with Ovarian Cancer Tumors. OncoTargets Ther. 2020, 13, 3595-3605. [CrossRef] [PubMed]

68. Kang, G.H.; Kim, K.M.; Park, C.K.; Kang, D.Y. PKC-theta expression in Ewing sarcoma/primitive neuroectodermal tumour and malignant peripheral nerve sheath tumour. Histopathology 2009, 55, 368-369. [CrossRef]

69. de Nardo, G.D.; Andreu, P.; Coussens, L.M. Interactions between lymphocytes and myeloid cells regulate pro- versus anti-tumor immunity. Cancer Metastasis Rev. 2010, 29, 309-316. [CrossRef] 